\title{
Healy Clean Coal Project
}

\section{Quarterly Report \\ October 1 - December 31, 1997}

Work Performed Under Contract No.: DE-FC22-91PC90544

For

U.S. Department of Energy

Office of Fossil Energy

Federal Energy Technology Center

Morgantown, West Virginia

By

Alaska Industrial Development and Export Authority

Anchorage, Alaska 


\section{Disclaimer}

This report was prepared as an account of work sponsored by an agency of the United States Government. Neither the United States Government nor any agency thereof, nor any of their employees, makes any warranty, express or implied, or assumes any legal liability or responsibility for the accuracy, completeness, or usefulness of any information, apparatus, product, or process disclosed, or represents that its use would not infringe privately owed rights. Reference herein to any specific commercial product, process, or service by trade name, trademark, manufacturer, or otherwise does not necessarily constitute or imply its endorsement, recommendation, or favoring by the United States Government or any agency thereof. The views and opinions of authors expressed herein do not necessarily state or reflect those of the United States Government or any agency thereof. 


\section{DISCLAIMER}

Portions of this document may be illegible in electronic image products. Images are produced from the best available original document. 


\begin{abstract}
The Healy Clean Coal Project, selected by the U.S. Department of Energy under Round III of the Clean Coal Technology Program, has been constructed and is currently in the Phase III Demonstration Testing. The project is owned and financed by the Alaska Industrial Development and Export Authority (AIDEA), and is cofunded by the U.S. Department of Energy. Construction was 100\% completed in mid-November of 1997 , with coal firing trials starting in early 1998. Demonstration testing and reporting of the results will take place in 1998 , followed by commercial operation of the facility. The emission levels of nitrogen oxides ( $\mathrm{NOx}$ ), sulfur dioxide $\left(\mathrm{SO}_{2}\right)$, and particulates from this 50-megawatt plant are expected to be significantly lower than current standards.
\end{abstract}




\section{TABLE OF CONTENTS}

Legal Notice $\quad 2$

Abstract 3

Section 1 - Executive Summary $\quad 6$

Section 2 - Introduction 6

Section 3 - Project Status 7

Section 4 - Summary and Plans for Next Quarter

Progress Schedule (Figure 1) 


\section{Acronyms and Abbreviations}

$\begin{array}{ll}\text { AIDEA } & \text { Alaska Industrial Development and Export Authority } \\ \text { AK } & \text { Alaska } \\ \text { DOE } & \text { U.S. Department of Energy } \\ \text { EPA } & \text { U.S. Environmental Protection Agency } \\ \text { EMP } & \text { Environmental Monitoring Plan } \\ \text { FWEC } & \text { Foster Wheeler Energy Corporation } \\ \text { GVEA } & \text { Golden Valley Electric Association, Inc. } \\ \text { HC Price } & \text { H.C. Price Company } \\ \text { HCCP } & \text { Healy Clean Coal Project } \\ \text { NEPA } & \text { National Environmental Policy Act } \\ \text { NPDES } & \text { National Pollution Discharge Elimination System } \\ \text { No. } & \text { Number } \\ \text { NOx } & \text { Nitrogen Oxides } \\ \text { OCIP } & \text { Owner Controlled Insurance Program } \\ \text { SCA } & \text { Sumitomo Corporation of America } \\ \text { SO2 } & \text { Sulfur dioxide } \\ \text { SWEC } & \text { Stone and Webster Engineering Corporation } \\ \text { TRW } & \text { TRW, Inc. } \\ \text { UCM } & \text { Usibelli Coal Mine, Inc. }\end{array}$




\section{SECTION 1 - SUMMARY}

Please refer to Quarterly Technical Progress Report No. 1, January 1, 1991, to June 30, 1991, for the project background and objectives for the Healy Clean Coal Project (HCCP). The report presented in the following text covers the period October 1, 1997, to December 31, 1997.

Construction of the project began in May of 1995 and was completed on November 21, 1997 , on schedule and within the budget established following the award of the general construction contract. Off-site manufacturing of equipment, including combustor supply and flue gas desulfurization system supply, was completed on schedule. Startup testing will be complete with the accomplishment of firing the combustors on coal during January of 1998, at which time the demonstration test period will begin.

Quarterly Technical Progress Report No. 28 summarizes the significant project development steps taken during the reporting period. The information is derived from the monthly reports, which are a more detailed chronology of events. The report concludes with a forecast of activities for the period of January 1, 1998, through March 31, 1998.

\section{SECTION 2 - INTRODUCTION}

This Quarterly Technical Progress Report is required under U.S. Department of Energy (DOE) Cooperative Agreement, Article XV, "Reporting Requirements" and Attachment C, "Federal Assistance Reporting Checklist". It covers the period of October 1, 1997, through December 31, 1997.

The primary objective of the HCCP is to conduct a cost-shared project that will demonstrate a new power plant design which features the innovative integration of an advanced combustor and heat recovery system coupled with both high- and lowtemperature emission control processes. The parties anticipate that if the demonstration project is successful, the technology could become commercialized in the near term and will be capable of (1) achieving significant reductions in the emissions of sulfur dioxide $\left(\mathrm{SO}_{2}\right)$ and the oxides of nitrogen $\left(\mathrm{NO}_{\mathrm{x}}\right)$ from existing facilities to minimize environmental impacts such as transboundary and interstate pollution and/or (2) providing for future energy needs in an environmentally acceptable manner.

The primary equipment elements comprising this new power plant design include entrained combustion (slagging) systems coupled with a boiler which will produce low$\mathrm{NO}_{x}$ levels, and function as a limestone calciner and first-stage $\mathrm{SO}_{2}$ remover in addition to its heat recovery function; a single spray dryer absorber vessel for second-stage $\mathrm{SO}_{2}$ removal; a baghouse for third-stage $\mathrm{SO}_{2}$ and particulate removal; and a lime activation 
system which recovers unused reagent from particulate collected in the baghouse. The emission levels of $\mathrm{SO}_{2}, \mathrm{NO}_{x}$, and particulate to be demonstrated are expected to be less than the Federal New Source Performance Standards (NSPS).

The HCCP is a 50-megawatt, coal-fired power plant built adjacent to the existing 25megawatt Healy Unit No. 1 that is owned and operated by Golden Valley Electric Association (GVEA). The scope of the project consists of a power plant utilizing an entrained combustion (slagging) system, with limestone injection, that burns coal in stages, and a spray dryer.

The Alaska Industrial Development and Export Authority (AIDEA) is administering state funds, performing under the Cooperative Agreement, and financing and owning the project through advance funding and the sale of bonds. DOE is providing cost-shared funding under the Cooperative Agreement to demonstrate advanced coal utilization technologies. AIDEA has assembled a team to design, build, supply coal, and operate the HCCP generating facility: GVEA, a member-owned cooperative electric utility that provides generation, transmission, and distribution service to the Fairbanks area, will operate the facility under an agreement with AIDEA and will purchase the power generated; Usibelli Coal Mine will furnish coal to GVEA; Stone and Webster Engineering Corporation will provide overall project engineering and management services; TRW and Babcock and Wilcox will provide $\mathrm{SO}_{2}$ and $\mathrm{NO}$ removal technology related to engineering, design, and manufacturing; and Foster Wheeler Energy Corporation will provide boiler expertise.

Construction of the project began in May of 1995. During the summer and fall of 1995, earthwork, foundation, and structural steel work were performed. No on-site construction was performed after the winter shutdown, which began in November of 1995. Construction began again in March of 1996. Equipment manufacture continued through the winter to be ready for installation throughout the balance of the construction process. Construction was completed on November 21, 1997. Startup testing will be complete with the accomplishment of firing the combustors on coal during January of 1998, at which time the demonstration test period will begin. Additional schedule details are provided on Figure 1 - Progress Schedule.

\section{SECTION 3 - PROJECT STATUS}

The following status is for Phase II (construction) work performed during the period October 1, 1997, to December 31, 1997, and is presented in bullet format listed by major activities.

\section{Project Management}

\section{Project Team}

The Healy Clean Coal Project (HCCP) team participants and their primary roles include: 
- Alaska Industrial Development and Export Authority (AIDEA) - Ownership, overall project management, and financing.

- Golden Valley Electric Association, Inc. (GVEA) - Design input and review, operator, and purchaser of the HCCP electrical output.

- Usibelli Coal Mine, Inc. (UCM) - Design input and review, coal supplier, and ash disposal.

- TRW, Inc. (TRW) - Entrained combustion (slagging) system technology supplier.

- Babcock \& Wilcox - Spray dryer, fabric filter, and ash recycle system technology supplier (formally Joy Environmental Technologies, Inc.).

- Stone and Webster Engineering Corporation (SWEC) - Architect/Engineer.

In addition, Foster Wheeler Energy Corporation (FWEC) has been contracted for design and supply of the boiler. Sumitomo Corporation of America (SCA) has been contracted for design and supply of the turbine/generator. H.C. Price Company (H.C. Price) has been contracted for general construction of the facility.

The required monthly reporting under the terms of the Cooperative Agreement, Article XV - Reporting Requirements, was fulfilled during this reporting period.

\section{Construction Management}

- AIDEA is leading the construction management effort with staff located in Anchorage and a project team located at the project site in Healy to manage the construction effort; administer all field services, supplier contracts, and material purchase orders; and provide direct construction coordination with the general contractor. AIDEA has retained an experienced manaser, who has extensive international experience in power plant construction. The manager is assisted by staff from AIDEA and technical specialists from SWEC having backgrounds suited for work in progress. In addition, support is provided as required from the SWEC office in Denver, Colorado, and off-site fabricators of equipment components.

- Construction was completed on November 21, 1997.

- All thirty-four (34) venders supplying the owner furnished equipment have made delivery. Over one hundred and ninety-three (193) train loads and five hundred and fifteen (515) truck loads of permanent materials and equipment were received at the site through October of 1996, at which time activity slowed dramatically. 
- On-site fabrication and erection of tanks and silos are complete. The tanks and silos were sandblasted and painted as installation occurred. On-site fabrication and installation of the Spray Dryer Absorber (SDA) is complete; on-site fabrication and erection of the stack was finished ahead of schedule; the Flue Gas Desulfurization (FGD) baghouse modules have been set and insulated; all ducting has been set in place; and the insulation and lagging of the combustors and piping, related to the boiler/combustor installation, is complete.

- Piping systems supporting the boiler hydrostatic tests were finished in March of 1997 and the boiler/combustor hydrostatic testing was completed successfully. The boiler chemical cleaning, boilout, and steam blows were successfully accomplished in June of 1997. Air compression and portions of the combined Unit No. 1 and HCCP coal handling system have been started up. Work on the mechanical and electrical tie-ins to Unit No. 1 is complete, and Unit No. 1 is now operating with the jointly shared coal handling systems and electrical control interfaces installed. During July of 1997, the boiler safety valves were set; the turbine main steam valve (MSV) was restored; the condenser and turbine systems were vacuum tested; and using steam produced by oil firing the boiler, the turbine was rolled, the generator was synchronized, and the turbine was loaded to produce 5 megawatts of electricity. Block construction throughout the plant and installation of the water treatment system equipment are finished, and work on the substation and $138 \mathrm{kv}$ line is complete.

- Construction meetings were held weekly with H.C. Price to review the construction schedule and progress, interface owner furnished equipment fabrication schedules, and to coordinate with Babcock and Wilcox, TRW, SCA, and FWEC, respectively, for the flue gas desulfurization system, combustors, turbine, and boiler deliveries and erection with general construction activities. By the end of December of 1997, six purchase orders remain to be closed and continue to be negotiated with the General Contractor and the suppliers.

- The final Environmental Monitoring Plan (EMP) was issued by AIDEA to DOE in April of 1997. DOE approved the final EMP in May of 1997.

- AIDEA received input from Babcock and Wilcox, TRW, and DOE on the Demonstration Test Plan. A preliminary draft was submitted to DOE in September of 1997, and at a meeting held in Denver on December, 4 of 1997, DOE agreed that AIDEA could proceed with the Demonstration Testing beginning on January 1, 1998. The final Demonstration Test Plan will be submitted in late April of 1998.

- AIDEA's engineers and vender representatives have provided extensive on-the-job and classroom training for GVEA operators as individual plant systems have been started up. Operating Manuals and Maintenance Manuals have been developed by the plant equipment vendors for AIDEA. In addition, turnover packages were completed for all the plant systems by the joint efforts of AIDEA's engineers and the General Contractor. 
- Start-up of all non-coal related systems was completed during this period.

\section{Finance}

- The construction process is within budget, with the contractor receiving $\$ 104,261,900$ through December 31, 1997, in progress payments towards the contract total of $\$ 103,366,512$. Change Orders 21 and 22, which amend the contract total, are in progress. The contract total cost figure includes two large change orders (Numbers 3 and 7 in Table 1) which merged erection of the boiler and turbine systems into the General Construction contract. Savings from deletion of these responsibilities from the supplier contracts resulted in a no net change in the overall project budget. Other changes are allocated to reserves for such purposes. Therefore, the project remains on budget. A summary of change orders to date is noted in Table 1.

Table 1 -Summary of Change Orders to General Construction Contract

\begin{tabular}{|c|c|c|}
\hline $\begin{array}{l}\text { Change } \\
\text { Order No. }\end{array}$ & Purpose & Cost \\
\hline 1 & Alaska State Fire Marshall changes & $\$ 825,000$ \\
\hline 2 & Construction Camp insurance adjustment & $\$ 400,000$ \\
\hline 3 & Boiler Erection - Moved from supplier contract & $\$ 14,576,611$ \\
\hline 4 & Fencing - Deletion & $(\$ 49,854)$ \\
\hline 5 & Touch-up Painting - Deletion & $(\$ 148,961)$ \\
\hline 6 & Borough Bed Tax - Added after bid date & $\$ 70,000$ \\
\hline 7 & Turbine Erection - Moved from supplier contract & $\$ 1,812,796$ \\
\hline 8 & Boiler Clean - Deletion & $(\$ 786,864)$ \\
\hline 9 & Ash and Disposal Credit - Net & $(\$ 167,538)$ \\
\hline 10 & Miscellaneous small changes & $\$ 52,654$ \\
\hline 11 & Camp Extension - Interim capacity & $\$ 180,000$ \\
\hline 12 & Engineering claim & $\$ 500,000$ \\
\hline 13 & Electrical/Instrumentation Drawing Revision & $\$ 212,801$ \\
\hline 14 & Additional Fireproofing & $\$ 1,340,218$ \\
\hline 15 & Various Small Changes & $\$ 24,473$ \\
\hline 16 & Force Account - Labor & $\$ 750,000$ \\
\hline 17 & Various Small Changes (COP's) & $\$ 217,060$ \\
\hline 18 & Usibelli and GVEA Contributions & $(\$ 291,312)$ \\
\hline 19 & Ash handling, boiler and misc. change orders & $\$ 59,823$ \\
\hline \multirow[t]{2}{*}{20} & Boiler weld claim and misc. change orders & $\$ 543,605$ \\
\hline & TOTAL CHANGE ORDERS TO DATE & $\$ 20,120,512$ \\
\hline
\end{tabular}

- Through this budgeting period, $\$ 237,421,500$ of project expenditures have been made $(98.1 \%$ of the project budget of $\$ 267,190,000)$. The project remains on schedule and within budget. 


\section{PERMITTING/NEPA COMPLiANCE}

The plant design is finalized and all federal and state permit related activities have been completed, and all permits necessary for the construction of the HCCP have been obtained. AIDEA is current in compliance with the permits, and representations made during the project's review under the provisions of the National Environmental Policy Act (NEPA). This review resulted in the issuance of a Final Environmental Impact Statement and Record of Decision that authorized construction of the Project. Mitigation Action Plan Annual Reports were submitted to DOE in September of 1996, and August of 1997.

Requests for Proposals were issued in August of 1997 for Visibility and Air Quality Monitoring programs. The awards were made in October of 1997, with systems expected to be operating in January of 1998.

\section{OWNER FURNISHED EQUIPMENT}

All vendors supplying owner furnished equipment have been delivered. The FWEC and SCA-related erection work has been consolidated under the scope of work of H.C. Price by a change order, providing a no net change in the project budget.

\section{Combustor Supply}

All major components of the TRW combustion system and the FWEC boiler components have been set in place and installation is complete. During July of 1997, the boiler tests were performed and using steam produced by oil firing the boiler, the turbine was the rolled, the generator was synchronized, and the turbine was loaded to produce 5 megawatts of electricity. Coal firing of the boiler has been rescheduled, at GVEA's request, and is now planned to begin in early January of 1998.

\section{FGD System Supply}

The Flue Gas Desulfurization (FGD) baghouse modules have been set in place. On-site fabrication and installation of the Spray Dryer Absorber (SDA) system is complete. Final preoperational testing of the HCCP coal handling, continuous emissions monitoring, fly ash/middle ash, and slag ash/bottom ash systems was completed in August of 1997.

\section{$\underline{\text { SCA }}$}

All components of the turbine, turbine auxiliary and piping, generator, embedded materials, electrical equipment, and instrumentation have been placed inside the plant in their final positions. Operational tests are anticipated in January of 1998. 


\section{Other Systems}

On-site fabrication and erection of the stack is finished and all of the ducting has been set in place. Placement of structural concrete is complete including floor slabs and foundations for the substation and coal handling system. Block construction throughout the plant, including the walls that adjoin Unit No. 1 and for the walls which form room partitions throughout the plant. Installation of the water treatment system equipment is finished and work on the substation $138 \mathrm{kv}$ line (electrical tie-ins to Unit No. 1) is complete. Healy Unit No. 1 is operating with the jointly shared coal handling systems and electrical control interfaces installed.

\section{Healy Unit No. 1 Retrofit}

Healy Unit No. 1 retrofit, excluding the sorbent injection system, is complete and on line. The NOx performance test of the boiler was delayed until December of 1998. The retrofit includes the addition of a Continuous Emission Monitoring System (CEMS), a boiler retrofit of low-NOx burners including necessary new pulverizers and air system modifications, and a sorbent injection system for $\mathrm{SO}_{2}$ control. The modifications are required by the HCCP and Healy Unit No. 1 air quality permits and associated agreements.

SECTION 4: SUMMARY AND PLANS FOR NEXT QUARTER (January 1, 1997, to March 31, 1998)

SUMMARY: Construction of the HCCP was completed on November 21, 1998, and initial startup of the individual plant systems has occurred. Major components of the boiler, combustor, turbine, and flue gas desulfurization systems have been pre-operationally checked out. Vender representatives for the Owner Furnished Equipment and the General Contractor Furnished Equipment will continue to be scheduled for job site visits, to witness and assist with equipment startup, and to provide on-the-job training to GVEA operators. Startup testing will be complete with the accomplishment of firing the combustors on coal, planned to be complete in January of 1998. The Demonstration Test Program begins in January of 1998 and is comprised of several test series, including performance guarantee acceptance tests, environmental compliance tests, major system characterization tests, and integrated system commercial operating condition tests. The overall test program strategy is based on first verifying that the individual components (fans, etc.) are meeting the specified performance guarantees, then characterizing the major systems (combustor, boiler, SDA) over a wide range of operating conditions and mapping the operating envelope for each major system, and finally characterizing the integrated system at the optimal operating conditions determined during the system characterization tests. Once the operating envelope for each system has been determined, each of the system's operating maps can be overlapped and the areas of the intersection will indicate the optimum operating envelope for the integrated system. 
PLANS: Specific activities planned for next quarter include:

\section{AIDEA}

- Oversight of project start-up and operations; and project management.

- Environmental Monitoring Plan is complete and has been approved by DOE. DOE agreed that AIDEA could proceed beginning on January 1, 1998, with the Demonstration Test Program at meetings held in Denver on December 4, 1997. The final Demonstration Test Plan is expected to be issued in April of 1998.

- AIDEA engineers will continue to provide on-the-job and classroom training for GVEA operators.

- AIDEA will continue to address outstanding issues with the General Contractor until AIDEA's final acceptance of the work occurs. Startup testing will be complete with the accomplishment of firing the combustors on coal, planned to be completed in January of 1998.

\section{Environmental}

- All state and federal permits have been acquired and AIDEA remains in compliance.

- Mitigation Action Plan Annual Reports were issued in September of 1996 and August of 1997.

- Requests for Proposals were issued in August of 1997 for Visibility and Air Quality Monitoring programs. The award was made in October of 1997, and the systems are expected to begin operating in January of 1998.

\section{TRW}

- Combustor systems were installed as part of the boiler erection and all related installation work has been completed and individual system testing of the combustor system has occurred. Startup testing will begin and include performance guarantee acceptance tests, environmental compliance tests, major system characterization tests, and integrated system commercial operating condition tests

\section{FWEC}

- The boiler system was delivered in June of 1996 and has been installed. Initial testing of the system has occurred and coal firing of the boiler will begin in mid-January of 1998. Startup testing will begin and include performance guarantee acceptance tests, environmental compliance tests, major system characterization tests, and integrated system commercial operating condition tests. 


\section{Babcock \& Wilcox}

- Engineering, design, fabrication, and installation of the spray dryer absorber and ash recycle system are complete and system testing has occurred. Startup testing will begin and include performance guarantee acceptance tests, environmental compliance tests, major system characterization tests, and integrated system commercial operating condition tests.

\section{$\underline{\text { SCA }}$}

- Installation of the turbine, turbine auxiliary and piping, generator, embedded materials, and electrical equipment is complete and systems testing has been completed. Startup testing will begin and include performance guarantee acceptance tests and integrated system commercial operating condition tests.

\section{SWEC}

- Response to requests for information from AIDEA will continue. In addition, SWEC will assist in demonstration testing as needed.

\section{Healy Unit No. 1 Retrofit}

- Healy Unit No. 1 retrofit and the Continuous Emissions Monitoring System (CEMS) installation is complete, excluding the sorbent injection system. The operational and performance testing have been delayed due to equipment problems. 


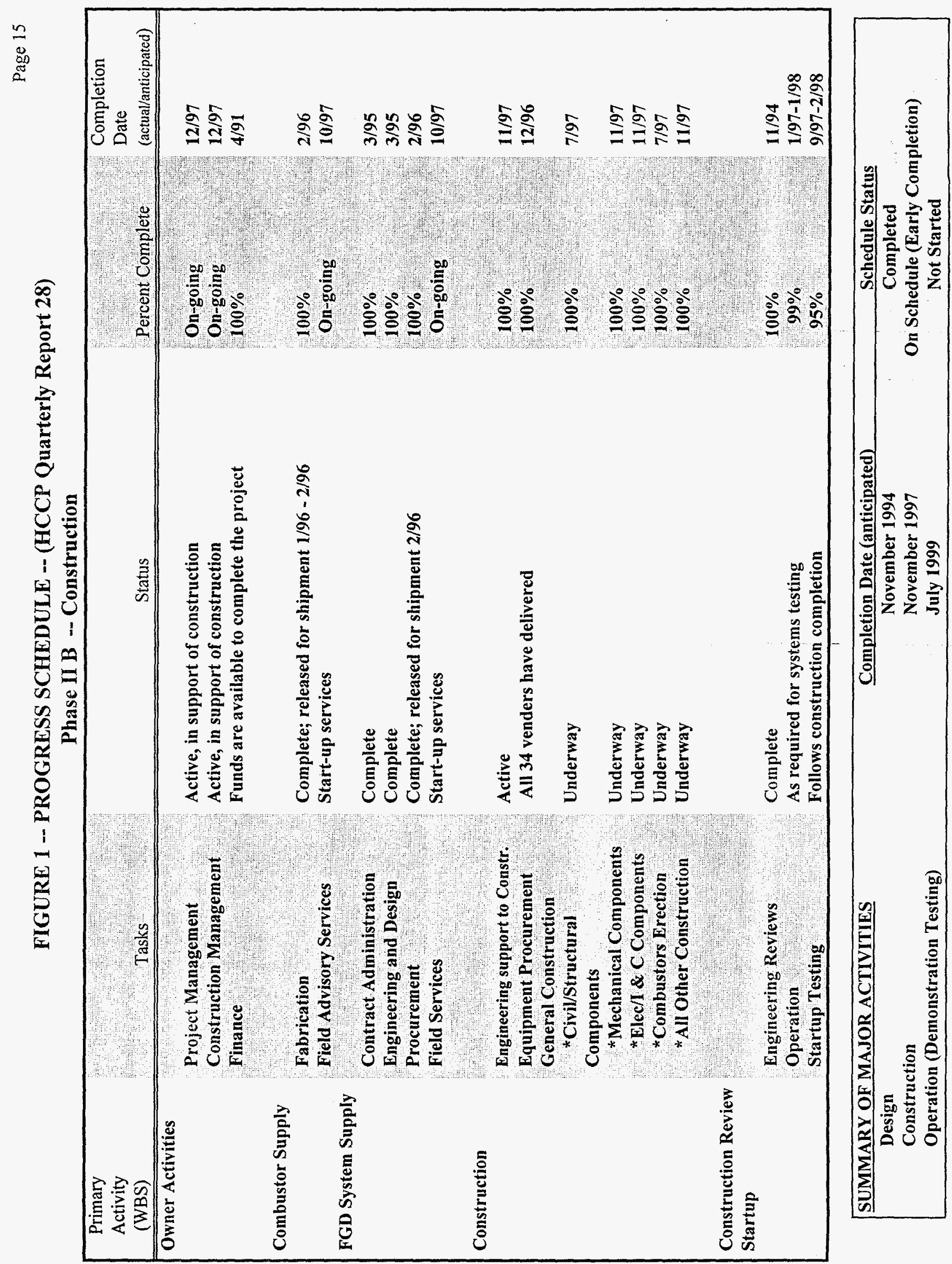

